\title{
PENYULUHAN PENGEMBANGAN KEPROFESIAN BERKELANJUTAN BAGI GURU SE-KECAMATAN BANGKINANG KABUPATEN KAMPAR
}

\author{
Elvrin Septyanti ${ }^{1}$, Hasnah Faizah ${ }^{2}$, Mangatur Sinaga $^{3}$, Charlina ${ }^{4}$, Hermandra $^{5}$ \\ Program Studi Pendidikan Bahasa dan Sastra Indonesia Universitas Riau \\ Email: elvrin.septyanti@ lecturer.unri.ac.id ${ }^{1}$, hasnah.faizah@ lecturer.unri.ac.id ${ }^{2}$, \\ mangatur.sinaga@lecturer.unri.ac.id ${ }^{3}$, charlina@lecturer.unri.ac.id ${ }^{4}$, hermandra@ lecturer.unri.ac.id ${ }^{5}$
}

\begin{abstract}
Abstrak
Pengabdian kepada masyarakat bertujuan untuk memberikan penyuluhan kepada guru se-kecamatan Bangkinang Kabupaten Kampar Provinsi Riau terkait program Pengembangan Keprofesian Berkelanjutan (PKB). Kegiatan ini diberikan kepada guru baik guru pada jenjang SD, SMP sederajat, SMA sederajat, dan SLB. Pengembangan Keprofesian berkelanjutan yang diberikan kepada guru pada program pengabdian ini terdiri dari 3 kegiatan, di antaranya kegiatan pengembangan diri, kegiatan publikasi ilmiah, dan karya inovatif yang perlu guru lakukan. Melalui kegiatan kepada masyarakat yang diberikan, para guru diharapkan memahami program pemerintah terkait kegiatan PKB dan dapat mengimplementasikan dalam ruang lingkup kerja. Hal ini juga dapat menunjang angka kredit guru untuk kenaikan pangkat bagi guru se-Kecamatan Bangkinang.
\end{abstract}

\section{Kata kunci: Penyuluhan, Program Pengembangan Keprofesian Berkelanjutan, Guru se-kecamatan Bangkinang}

\begin{abstract}
Community service aims to educate teachers in the Bangkinang sub-district, Kampar District, Riau Province regarding the Continuing Professional Development (PKB) program. This activity is given to teachers both teachers at elementary, junior high school level, high school equivalent, and SLB. Continuous professional development given to teachers in this service program consists of 3 activities, including selfdevelopment activities, scientific publication activities, and innovative work that teachers need to do. Through the activities given to the community, teachers are expected to understand government programs related to PKB activities and can implement them within the scope of work. This can also support the teacher's credit score for promotion for teachers throughout Bangkinang District.
\end{abstract}

\section{Keywords: Counseling, Sustainable Professional Development Program, Teachers in Bangkinang sub-district}

\section{Pendahuluan}

Peraturan Pemerintah No 19 Tahun 2005 tentang Standar Nasional Pendidikan (Lembaran Negara Republik Indonesia Tahun 2005 Nomor 41), Tambahan Lembaran Negara Republik Indonesia Nomor 4496), sebagaimana telah beberapa kali diubah terakhir dengan Peraturan Pemerintah Nomor 13 Tahun 2015 tentang Perubahan kedua Atas Peraturan Pemerintah
Nomor 19 Tahun 2005 tentang Standar Nasional Pendidikan (Lembaran Negara Republik Indonesia Tahun 2015 nomor 45, Tambahan Lembaran Negara Republik Indonesia Nomor 5670) mengamanatkan guru sebagai tenaga profesional yang wajib melakukan kegiatan pengembangan keprofesian secara berkelanjutan guna mendukung pengembangan profesionalisme guru pembelajar (PPGP). 
Pelaksanaan kegiatan pengembangan keprofesian berkelanjutan sebagaimana yang diamanatkan dalam Peraturan Menteri Negara Pendayagunaan Aparatur Negara dan Reformasi Birokrasi Nomor 16 Tahun 2009 tentang Jabatan Fungsional Guru dan Angka Kreditnya, diharapkan dapat menciptakan guru profesional, mampu menumbuhkembangkan minat dan bakat peserta didik sesuai dengan bidangnya dalam menguasai ilmu pengetahuan, teknologi, dan seni. Guru sebagai pembelajar abad ke-21 harus mampu mengikuti perkembangan ilmu dalam bidangnya dan dapat memberikan bekal pengetahuan, keterampilan dan sikap yang sesuai dengan standar kompetensi yang harus dimiliki peserta didik.

Berkaitan dengan penjelasan pada paragraf terdahulu, perlu diberikan penyuluhan kepada guru di seluruh Indonesia. Urgensi penyuluhan itu adalah untuk menyosialisasikan kebijakan baru tentang kegiatan Pengembangan Keprofesian Berkelanjutan.

Di dalam Kata Pengantar Buku Pedoman Pengelolaan Pengembangan Keprofesian Berkelanjutan Guna Mendukung Pengembangan Profesi Guru Pembelajar (PPGP) Direktur Jenderal Guru dan Tenaga Kependidikan, Sumarna Surapranata, Ph.D. mengatakan bahwa "Guru yang profesional wajib melakukan kegiatan pengembangan keprofesian berkelanjutan". Kegiatan pengembangan keprofesian berkelanjutan itu terbagi tiga, yakni (A) melaksanakan pengembangan diri, yang terbagi atas dua kegiatan, (B) publikasi ilmiah, yang terdiri atas empat kegiatan, dan (C) karya inovatif, yang terdiri atas empat kegiatan.

Berdasarkan dialog Dr. Mangatur Sinaga, M.Hum. dengan KUPTD Dikpora Kecamatan Bangkinang, H. Hendrik, S.Pd., guru se-Kecamatan memerlukan informasi tentang pengembangan diri, publikasi ilmiah, dan karya inovatif. Guru seKecamatan Bangkinang bertugas di 35 sekolah: SD, SMP Negeri dan Swasta/MTs Swasta, SMA/MA, dan SLB. Dengan demikian, latar belakang penyuluhan ini adalah (1) Permenneg PAN dan RB Nomor 16 Tahun 2009, unsur kegiatan pengembangan keprofesian berkelanjutan yang berisi tentang kewajiban guru untuk melaksanakan pengembangan diri, melaksanakan publikasi ilmiah, dan menghasilkan karya inovatif dan (2) guru se-Kecamatan belum mendapatkan penyuluhan tentang isi Permenneg PAN dan RB Nomor 16 Tahun 2009 tentang tentang kewajiban guru untuk melaksanakan pengembangan diri, melaksanakan publikasi ilmiah, dan menghasilkan karya inovatif.

Tujuan umum kegiatan pengabdian ini untuk meningkatkan pemahaman guru seKecamatan Bangkinang tentang isi Permenneg PAN dan RB Nomor 16 Tahun 2009 tentang unsur kegiatan pengembangan keprofesian berkelanjutan. Secara khusus, kegiatan pengabdian ini bertujuan: meningkatkan pemahaman guru seKecamatan Bangkinang tentang unsur pengembangan diri, unsur publikasi, dan unsur karya inovatif berdasarkan Permenneg PAN dan RB Nomor 16 Tahun 2009.

Pengembangan Keprofesian Berkelanjutan Guna Mendukung Pengembangan Profesi Bagi Guru Pembelajar (PPGP) adalah pengembangan kompetensi guru yang dilaksanakan sesuai dengan kebutuhan, secara bertahap, berkelanjutan untuk meningkatkan profesionalitas guru. Dengan demikian, guru dapat memelihara, meningkatkan, dan memperluas pengetahuan dan keterampilannya untuk melaksanakan proses pembelajaran secara profesional. 
Pembelajaran yang berkualitas diharapkan mampu meningkatkan pengetahuan, keterampilan, dan sikap peserta didik. Pengembangan keprofesian berkelanjutan guna mendukung pengembangan profesi bagi guru pembelajar (PPGP) mencakup kegiatan perencanaan yang diawali dari hasil evaluasi diri, Uji kompetensi guru (UKG), dan Penilaian Kinerja Guru (PK Guru) oleh Kepala Sekolah dan/atau tim penilai sekolah pada pelaksanaan pembelajaran di kelas dan tugas lainnya. Penilaian Kinerja Guru yang didesain untuk meningkatkan karakteristik, pengetahuan, pemahaman dan keterampilan, sebagaimana digambarkan pada diagram berikut ini (diadopsi dari Center for Continuous Professional Development (CPD). University of Cincinnati Academic Health Center (http://webcentral.uc.edu/cpd_online2). Melalui siklus evaluasi, refleksi pengalaman belajar, perencanaan dan implementasi kegiatan PPGP, guru diharapkan mampu meningkatkan kompetensi pedagogik, profesional, sosial, dan kepribadian untuk pelaksanaan pembelajaran yang berdampak pada pengembangan kariernya.

Pengembangan keprofesian berkelanjutan guna mendukung Mengembangan profesi bagi guru pembelajar (PPGP) dilaksanakan sesuai dengan kebutuhan guru. Pelaksanaannya didasarkan pada unsurunsur pengembangan keprofesian berkelanjutan bagi guru pembelajar (PPGP), prinsip pelaksanaan, dan lingkup pelaksanaan kegiatan.

1. Unsur Pengembangan Keprofesian Berkelanjutan Guna Mendukung Pengembangan Profesi Bagi Guru Pembelajar (PPGP) Menurut Permenneg PAN dan RB Nomor 16 Tahun 2009, unsur kegiatan pengembangan keprofesian berkelanjutan meliputi kegiatan-kegiatan berikut.

a. Pengembangan Diri

Kegiatan pengembangan diri adalah upaya untuk meningkatkan profesionalisme diri agar memiliki kompetensi yang sesuai dengan peraturan perundang-undangan atau kebijakan pendidikan nasional serta perkembangan ilmu pengetahuan, teknologi dan/atau seni. Kegiatan tersebut dilakukan melalui pendidikan dan pelatihan (diklat) fungsional, teknis dan/atau melalui kegiatan kolektif guru.

1) Diklat Fungsional dan Teknis

Kegiatan diklat fungsional dan teknis, sesuai dengan amanat Peraturan Pemerintah Nomor 101 Tahun 2000 tentang Pendidikan dan Pelatihan Jabatan Pegawai Negeri Sipil pasal 8 (ayat 1) menyatakan bahwa diklat dalam jabatan dilaksanakan untuk mengembangkan pengetahuan, keterampilan, dan sikap Pegawai Negeri Sipil agar dapat melaksanakan tugas-tugas pemerintahan dan pembangunan dengan sebaikbaiknya. Di dalam pasal yang sama (ayat 2), dinyatakan bahwa diklat dalam jabatan terdiri dari diklat kepemimpinan, diklat fungsional, dan diklat teknis. Selanjutnya, pasal 11 (ayat 1) menyatakan bahwa diklat fungsional dan teknis dilaksanakan untuk mencapai persyaratan Kompetensi yang sesuai dengan jenis dan jenjang jabatan fungsional masing-masing jenis dan jenjang jabatan fungsional. Diklat dapat dilaksanakan secara tatap muka maupun jarak jauh dengan korespondensi atau berbasis internet (daring/dalam jaringan). Jenis diklat dapat berupa pelatihan, Penataran, bimbingan teknis, bimbingan karier, kursus, magang atau bentuk lain yang diakui oleh instansi yang 
berwenang. Sejalan Dengan hal di atas, Permendiknas Nomor 35 Tahun 2010 tentang Petunjuk Teknis Jabatan Fungsional Guru dan Angka Kreditnya, menyatakan bahwa diklat fungsional adalah kegiatan guru dalam mengikuti pendidikan atau pelatihan yang bertujuan untuk meningkatkan keprofesian guru yang bersangkutan dalam kurun waktu tertentu. Diklat fungsional dan teknis harus dibuktikan dengan surat tugas, sertifikat/surat keterangan dilengkapi struktur program, dan laporan deskripsi hasil pelatihan yang disahkan oleh kepala sekolah atau atasannya.

2) Kegiatan Kolektif Guru Kegiatan kolektif guru adalah kegiatan guru dalam mengikuti kegiatan pertemuan ilmiah atau mengikuti kegiatan bersama yang dilakukan guru baik di sekolah maupun di luar sekolah (seperti KKG/MGMP/ MGBK) yang bertujuan untuk meningkatkan keprofesian guru.

Pelaksanaan kegiatan pertemuan kolektif guru di KKG/MGMP/MGBK dilaksanakan minimun 12 kali pertemuan dalam satu tahun. Di dalam kegiatan kolektif dimaksud dapat membahas beberapa topik kegiatan dalam satu tahun dengan ketentuan satu topik kegiatan minimal dilaksanakan dalam tiga kali pertemuan untuk membahas tentang materi/topik tertentu, sehingga dalam satu tahun guru paling tidak membahas 4 materi/topik yang dilaksanakan untuk 12 kali pertemuan. Beberapa contoh bentuk kegiatan kolektif guru antara lain sebagai berikut.

a) Mengikuti lokakarya atau kegiatan kelompok/musyawarah kerja guru atau in house training untuk penyusunan perangkat kurikulum dan/atau kegiatan pembelajaran termasuk pembelajaran berbasis TIK, penilaian, pengembangan media pembelajaran, dan/atau kegiatan lainnya untuk kegiatan pengembangan keprofesian berkelanjutan bagi guru.

b) Mengikuti seminar, koloqium, diskusi panel, atau bentuk pertemuan ilmiah lainnya, baik sebagai pembahas maupun sebagai peserta. Seminar tersebut tidak termasuk seminar laporan hasil penelitian yang dilakukan guru tersebut.

c) Mengikuti kegiatan kolektif lain yang sesuai dengan tugas dan kewajiban guru terkait dengan pengembangan keprofesiannya (studi banding, kemitraan, dan sejenisnya).

Kegiatan kolektif guru harus dibuktikan dengan surat tugas dari kepala sekolah atau atasan langsungnya yang dilengkapi pengesahan oleh instansi yang terkait dan laporan deskripsi hasil kegiatan yang disahkan oleh kepala sekolah atau atasan langsungnya. Beberapa contoh materi yang dapat dikembangkan dalam kegiatan pengembangan diri, baik dalam diklat fungsional maupun kegiatan kolektif guru, antara lain: (1) perencanaan pendidikan dan program kerja; (2) pengembangan kurikulum, penyusunan Rencana Pelaksanaan Pembelajaran (RPP) dan pengembangan bahan ajar; pengembangan metodologi mengajar; (4) penilaian proses dan hasil pembelajaran peserta didik; (5) penggunaan teknologi informasi dan komunikasi (TIK) dalam pembelajaran; (6) inovasi proses pembelajaran; (7) peningkatan kompetensi profesional dalam menghadapi tuntutan teori terkini; (8) penulisan publikasi ilmiah; (9) pengembangan karya inovatif; (10) kemampuan untuk mempresentasikan hasil karya; dan (11) peningkatan kompetensi lain yang terkait dengan pelaksanaan tugastugas tambahan atau tugas lain yang relevan dengan fungsi sekolah/madrasah. Kegiatan pengembangan diri yang dilaksanakan di sekolah seperti in house training harus 
sesuai dengan kebutuhan guru dan sekolah, serta dikoordinasikan oleh kepala sekolah dan/atau koordinator pengembangan keprofesian berkelanjutan bagi guru pembelajar (PPGP).

Guru yang telah mengikuti diklat fungsional dan/atau kegiatan kolektif guru berkewajiban membuat laporan kegiatan yang telah diikuti tersebut. Guru yang membuat laporan dari hasil kegiatan yang diikuti tersebut akan memperoleh penghargaan berupa angka kredit sesuai peraturan yang berlaku.

\section{b. Publikasi Ilmiah}

Publikasi ilmiah adalah karya tulis ilmiah yang telah dipublikasikan kepada masyarakqat sebagai bentuk kontribusi guru terhadap peningkatan kualitas proses pembelajaran di sekolah dan pengembangan dunia pendidikan secara umum.

Publikasi ilmiah mencakup 3 (tiga) kelompok, yaitu:

1) Presentasi pada forum ilmiah. Dalam hal ini, guru bertindak sebagai pemrasaran dan/atau narasumber pada seminar, lokakarya, koloqium, dan/atau diskusi ilmiah baik yang diselenggarakan pada tingkat sekolah, KKG/MGMP/ MGBK.

2) Publikasi ilmiah berupa hasil penelitian atau gagasan ilmu bidang pendidikan formal. Publikasi dapat berupa karya tulis hasil penelitian, makalah tinjauan ilmiah di bidang pendidikan formal dan pembelajaran, tulisan ilmiah populer, dan artikel ilmiah dalam bidang pendidikan. Karya ilmiah ini telah diterbitkan dalam jurnal ilmiah tertentu atau minimal telah diterbitkan dan diseminarkan di sekolah masing-masing. Dokumen karya ilmiah disahkan oleh kepala sekolah dan disimpan di perpustakaan sekolah. Bagi guru yang mendapat tugas tambahan sebagai kepala sekolah, karya ilmiahnya harus disahkan oleh kepala dinas pendidikan setempat.

3) Publikasi buku teks pelajaran, buku pengayaan, dan/atau pedoman guru. Buku yang dimaksud dapat berupa buku pelajaran, baik sebagai buku utama maupun buku pelengkap, modul/diktat pembelajaran per semester, buku dalam bidang pendidikan, karya terjemahan, dan buku pedoman guru. Buku tersebut harus tersedia di perpustakaan sekolah tempat guru bertugas. Keaslian buku harus ditunjukkan dengan pernyataan keaslian dari kepala sekolah atau dinas pendidikan setempat bagi guru yang mendapatkan tugas tambahan sebagai kepala sekolah.

\section{c. Karya inovatif}

Karya inovatif adalah karya yang bersifat pengembangan, modifikasi atau penemuan baru sebagai bentuk kontribusi guru terhadap peningkatan kualitas proses pembelajaran di sekolah dan pengembangan dunia pendidikan, sains/teknologi, dan seni. Karya inovatif ini dapat berupa penemuan teknologi tepat guna, penemuan/penciptaan atau pengembangan karya seni, pembuatan/modifikasi alat pelajaran/ peraga/praktikum, atau penyusunan standar, pedoman, soal, dan sejenisnya pada tingkat nasional maupun provinsi.

Tabel 1

Pengembangan Keprofesian Berkelanjutan 


\begin{tabular}{|c|c|c|c|}
\hline \multicolumn{4}{|c|}{ Unsur PPGP } \\
\hline No & Subunsur PPGP & No & Kegiatan \\
\hline \multirow[t]{2}{*}{ A } & \multirow{2}{*}{$\begin{array}{l}\text { Melaksanakan } \\
\text { Pengembangan } \\
\text { Diri }\end{array}$} & 1. & $\begin{array}{l}\text { Mengikuti diklat } \\
\text { fungsional }\end{array}$ \\
\hline & & 2 . & $\begin{array}{l}\text { Melaksanakan } \\
\text { kegiatan kolektif guru }\end{array}$ \\
\hline \multirow[t]{4}{*}{$\mathrm{B}$} & \multirow[t]{4}{*}{ Publikasi Ilmiah } & 1 . & $\begin{array}{l}\text { Membuat karya tulis } \\
\text { ilmiah dan } \\
\text { mempublikasikan } \\
\text { hasil penelitian }\end{array}$ \\
\hline & & 2. & $\begin{array}{l}\text { Membuat karya tulis } \\
\text { ilmiah dan } \\
\text { mempublikasikan } \\
\text { tinjauan ilmiah }\end{array}$ \\
\hline & & 3. & $\begin{array}{l}\text { Membuat karya tulis } \\
\text { ilmiah dan } \\
\text { mempublikasikan buku }\end{array}$ \\
\hline & & 4. & $\begin{array}{l}\text { Membuat karya tulis } \\
\text { ilmiah dan } \\
\text { mempublikasikan } \\
\text { modul, dan sejenisnya }\end{array}$ \\
\hline \multirow[t]{4}{*}{$\mathrm{C}$} & \multirow[t]{4}{*}{ Karya Inovatif } & 1 & $\begin{array}{l}\text { Menemukan teknologi } \\
\text { tepat guna }\end{array}$ \\
\hline & & 2. & $\begin{array}{l}\text { Menemukan/mencipta } \\
\text { kan karya seni }\end{array}$ \\
\hline & & 3. & $\begin{array}{l}\text { Membuat/memodifikas } \\
\text { i alat pelajaran }\end{array}$ \\
\hline & & 4. & $\begin{array}{l}\text { Mengikuti } \\
\text { pengembangan } \\
\text { penyusunan } \\
\text { standar, pedoman, soal } \\
\text { dan sejenisnya }\end{array}$ \\
\hline
\end{tabular}

\section{Bahan dan Metode Pelaksanaan}

Kegiatan pengabdian kepada masyarakat ini dilaksanakan pada hari Sabtu, 26 Agustus 2017 dengan materi konseptual dan dilanjutkan kegiatan mengerjakan produk pada tanggal 2,9 , dan 16 September 2017. Berikut ini dideskripsikan kegiatan yang dilakukan. Pembukaan acara dilakukan oleh KUPTD Dikpora Kecamatan Bangkinang yaitu $\mathrm{H}$. Hendri, S.Pd. Berdasarkan daftar hadir, yang mengikuti pelatihan berjumlah 41 orang.

Narasumber pada kegiatan ini adalah dosen di lingkungan program studi Pendidikan Bahasa dan Sastra Indonesia FKIP Universitas Riau. Secara rinci materi yang disampaikan dideskripsikan dalam uraian berikut.

\section{1) Registrasi dan Pembukaan}

Registrasi peserta dan pembukaan pelatihan berlangsung mulai pukul 08.00 Wib. sampai dengan pukul 09.00 WIB. Pembukaan acara dilakukan oleh KUPTD Dikpora Kecamatan Bangkinang yaitu $\mathrm{H}$. Hendri, S.Pd. Berdasarkan daftar hadir, yang mengikuti pelatihan berjumlah 41 orang.

\section{2) Penyajian Materi 1}

Kegiatan menyajikan materi pelatihan mulai dilaksanakan pukul 09.30 WIB sampai dengan pukul 11.30 WIB. Pemateri adalah Dr. Mangatur Sinaga, M.Hum. Kegiatan dimulai dengan Pedoman kegiatan PKB. Peserta pengabdian ini adalah guru baik dari tingkat SD, SMP, SMA, dan SLB yang tersebar di kecamatan Bangkinang berjumlah 41 orang. Materi selanjutnya, disampaikan oleh Elvrin Septyanti, S.Pd., M.Pd. dengan pokok bahasan Jenis PKB.

Kegiatan berlangsung secara efektif. Peserta sangat aktif. Mereka tertarik dengan materi yang disajikan. Hal ini disebabkan karena program pemerintah mengenai PKB belum sampai secara menyeluruh.

\section{3) Penyajian Materi 2}

Pada kegiatan kedua ini, pemateri yang bertanggungjawab menyampaikan konsep pengabdian adalah Prof. Dr. Hasnah Faizah, M.Hum. Beliau adalah guru besar bidang pembelajaran Bahasa Indonesia Universitas Riau. Materi pada kegiatan ini adalah publikasi ilmiah. Peserta dibekali sejumlah pengetahuan mengenai kewajiban publikasi ilmiah bagi guru. Selain itu, Dr. Charlina, M.Hum. Juga menyampaikan kelanjutan materi mengenai publikasi ilmiah mengenai jumlah angka kredit yang harus dicapai masing-masing guru berdasarkan pangkat/ golongan guru yang bersangkutan.

Problematika yang muncul menunjukkan bahwa mayoritas guru atau peserta yang hadir belum banyak 
mengetahui mengenai program perkembangan keprofesian berkelanjutan khususnya cara mempublikasikan karya ilmiah yang telah disusun.

\section{4) Penyajian Materi 3}

Materi ketiga disampaikan oleh Dr. Hermandra, M.A. Adapun materi yang disampaikan mengenai karya inovatif yang harus dibuat oleh guru. Karya inovatif ini dapat dilakukan guna menunjang kegiatan pembelajaran di kelas bagi guru itu sendiri. Bentuk karya inovatif dapat berupa CD interaktif, media pembelajaran interaktif, alat peraga, dan sejenisnya. Selama kegiatan berlangsung, pemateri 3 selalu mengawasi dan mengoreksi langsung dari apa yang dipermasalahkan oleh peserta.

\section{5). Kegiatan Praktik pada 2, 9, dan 16 September 2017}

Pada masa ini, kegiatan yang dilakukan adalah tindak lanjut dari kegiatan sebelumnya. Peserta ditugaskan untuk membuat rencana kegiatan mengenai 3 kegiatan pengembangan keprofesian berkelanjutan yang meliputi, 1) pengembangan diri, 2) publikasi ilmiah, dan 3) karya inovatif. Berdasarkan penyuluhan yang telah dilakukan diketahui bahwa informasi mengenai PKB belum sampai kepada guru-guru di Bangkinang. Adapun hambatan yang dihadapi diantaranya.

1) Belum pernah mengikuti pelatihan mengenai PKB.

2) Kurangnya sosialisasi mengenai PKB ke guru di kecamatan Bangkinang

3) Kegiatan diklat, seminar, dan sejenisnya bersamaan dengan jam efektif guru sehingga timbul keraguan untuk mengikuti kegiatan di luar kelas

4) Tidak ada tempat berkonsultasi bagi guru di daerah

\section{Hasil dan Pembahasan}

Kegiatan pengabdian kepada masyarakat yang dilakukan di Bangkinang, Riau mengahasilkan luaran berupa laporan hasil pengabdian. Adapun kegiatan presentasi terkait kegiatan pengabdian masyarakat membahas 3 topik Pengembangan Keprofesian Berkelanjutan.

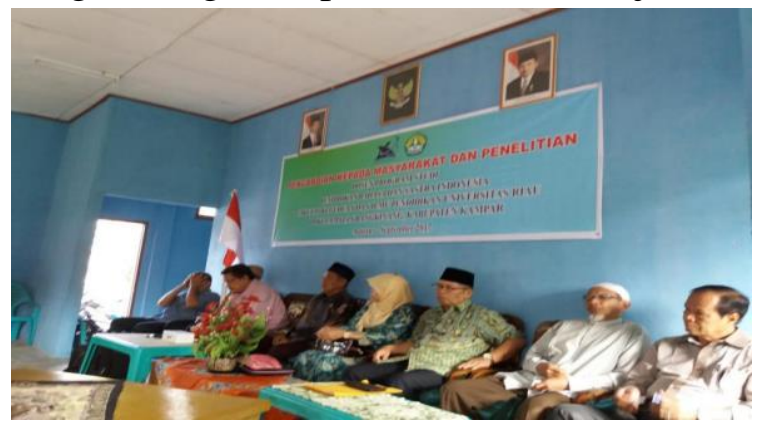

\section{Pengembangan Diri}

Kegiatan pemaparan oleh tim dosen, dibuka dengan materi pengenalan konsep Pengembangan Keprofsian Berkelanjutan dan Jenis Pengembangan Keprofesian Berkelanjutan. Berdasarkan kegiatan penyuluhan, guru baik jenjang SD, SMP, SMA, SLB kesulitan mendapat referensi terkait kegiatan pengembangan diri yang dapat diikuti guru. Pengetahuan guru terkait nilai angka kredit yang dapat diperoleh guru guna menunjang kenaikan pangkat juga sangat minim. Kesempatan untuk mengikuti kegiatan, seperti pelatihan/workshop, sosialisasi, penyuluhan, dan sejenisnya juga jarang diikuti.

\section{Publikasi Ilmiah}

Publikasi ilmiah adalah satu satu kegiatan menulis yang harus dilakukan oleh guru. Beberapa guru daerah kesulitan untuk mempublikasi hasil penelitian. Guru di daerah kecamatan Bangkinang juga jarang mengikuti dan atau menyeminarkan hasil penelitian mereka di kegiatan Seminar baik bersifat lokal, nasional, maupun internasional. 


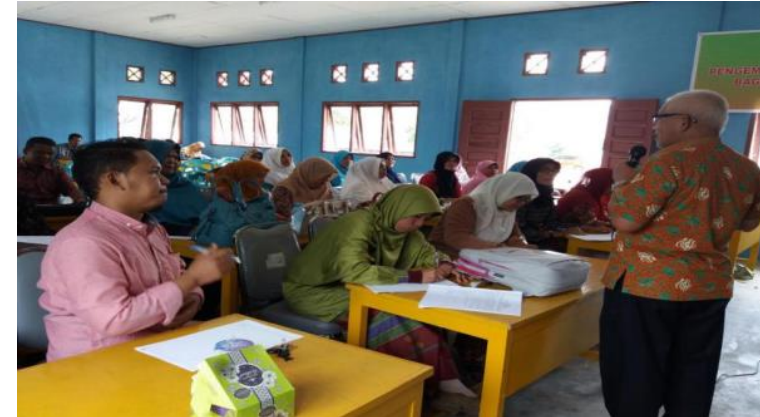

Karya Inovarif

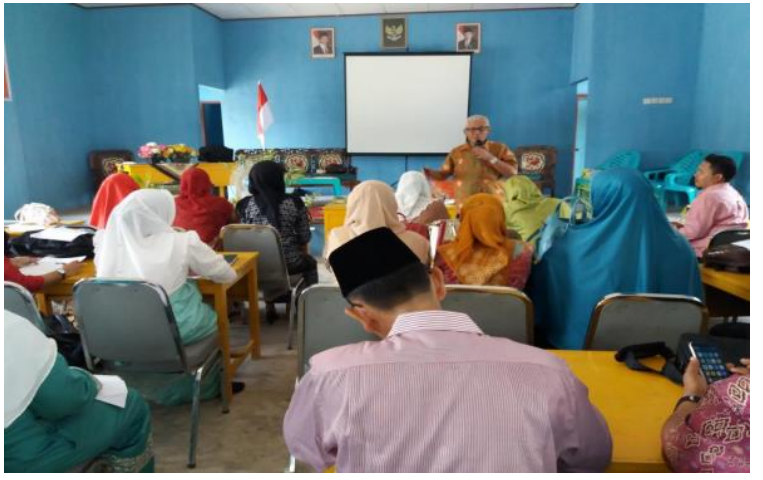

Di era kurikulum 13, guru hendaknya memberikan pengalaman belajar kepada peserta didik yang menyenangkan. Sebagai fasilitator, guru diminta untuk kreatif dan inovatif dalam menyampaikan materi ajar yang ada pada kompetensi inti dan indikator yang diharapkan. Karya inovatif menjadi bagian penilaian angka kredit yang dapat diperoleh guru jika menciptakan satu model atau media pembelajaran baik baru maupun modifikasi dalam proses pembelajaran. Kegiatan ini yang masih jarang dilakukan guru.

\section{Evaluasi}

Kegiatan pengabdian diakhiri dengan evaluasi kegiatan. Peserta pelatihan diminta mengisi angket terkait pemahaman guru sekecamatan Bangkinang mengenai Pengembangan Keprofesian Berkelanjutan bagi guru. Hal ini diharapkan menjadi acuan bagi penyelenggara pengabdian perihal kerja sama lanjutan dengan pihak UPTD setempat terkaitkegiatan yang dapat memfasilitasi para guru se-kecamatan Bangkinang dalam mengikuti 3 pergiatan $\mathrm{PKB}$, seperti pengembangan diri, publikasi ilmiah, dan karya inovatif.

\section{Simpulan}

Berdasarkan data yang diperoleh bahwa guru SD, SMP, SMA, dan SLB yang mengikuti kegiatan penyuluhan mengenai Pengembangan Keprofesian Berkelanjutan bagi Guru, masih banyak guru yang belum mengetahui program PKB. Kegiatan yang berkenaan dengan PKB, seperti pengembangan diri, publikasi ilmiah, dan karya inovatif juga jarang dilakukan oleh guru di kecamatan Bangkinang. Adapun hambatan yang dihadapi di antaranya.

a) Belum pernah mengikuti bimtek mengenai $\mathrm{PKB}$

b) Kurangnya sosialisasi mengenai PKB ke guru di kecamatan Bangkinang

c) Kegiatan diklat, seminar, dan sejenisnya bersamaan dengan jam efektif guru sehingga timbul keraguan untuk mengikuti kegiatan di luar kelas

d) Tidak ada tempat berkonsultasi bagi guru di daerah 